\title{
Energy Outputs and Financial Returns of On-Farm Biodigester Systems in the United States: A Case Study in Vermont
}

\author{
Qingbin Wang*, Ethan Thompson, Laurel Valchuis, Robert Parsons \\ Department of Community Development and Applied Economics, University of Vermont, Burlington, USA \\ Email address: \\ qwang@uvm.edu (Qingbin Wang), enthomps@uvm.edu (E. Thompson), lvalchuis@uvm.edu (L. Valchuis), \\ bob.parsons@uvm.edu (R. Parsons) \\ ${ }^{*}$ Corresponding author
}

\section{To cite this article:}

Qingbin Wang, Ethan Thompson, Laurel Valchuis, Robert Parsons. Energy Outputs and Financial Returns of On-Farm Biodigester Systems in the United States: A Case Study in Vermont. International Journal of Sustainable and Green Energy. Vol. 6, No. 2, 2017, pp. 10-18. doi: $10.11648 /$ j.jirse.20170602.11

Received: February 20, 2017; Accepted: March 14, 2017; Published: April 11, 2017

\begin{abstract}
This study assesses the investments, energy outputs, and financial returns of on-farm anaerobic digester systems (ADS) by farm size through a case study in Vermont and discusses the potential policy implications. Detailed data on the initial investments, production of electricity and other marketable products, operational expenses, and income, collected through surveys of eight operating ADS on dairy farms in Vermont, are used to estimate the return on equity (ROE), return on assets (ROA), and other financial indicators for small, medium, and large farms. The primary survey data indicate that the average investment was $\$ 1.35$ million for small and medium farms (75-500 cows) and $\$ 2.44$ million for large farms ( $>500$ cows). Financial analysis indicates that the ROE and ROA were $12.54 \%$ and $13.50 \%$ for large farms but only $0.73 \%$ and $1.07 \%$ for small and medium dairy farms, respectively. Whereas the technology of ADS developed in the United States seems to favor large farms in terms of both energy production and financial returns, the centralized ADS developed in Europe and low-cost mini digesters developed in China may have potentials for small and medium farms to develop more economically viable ADS in the United States.
\end{abstract}

Keywords: Anaerobic Digester System, Renewable Energy, Dairy Farms, Economics, Vermont

\section{Introduction}

Many American dairy farms, especially small and medium farms, have been struggling to stay in business and, as a result, the number of dairy farms has declined steadily across the United States in the past three decades. For example, in the state of Vermont, the number of dairy farms has dropped steadily since 1980 , from 3,372 in 1980 to 2,370 in 1990; to 1,569 in 2000; and to only 868 in 2014 [1]. Although many factors have contributed to the problems faced by dairy farms, rising production costs and fluctuating farm gate milk prices are the major causes [2]. While there may not be any simple solution to the challenges faced by dairy farms, converting cow manure and other agricultural wastes into biogas, electricity, and other marketable products via anaerobic digester systems (ADS) is one avenue for some dairy farmers to diversify their production practices and increase farm income [3]. For example, Wang et al. reported that the ADS on four Vermont dairy farms generated an average of $\$ 474,239$ revenue per farm per year from the sales of electricity and solid materials used as animal bedding or compost [3]. In addition to the marketable products and farm income, the on-farm ADS have also shown many environmental benefits such as reduction of greenhouse gas (GHG) emissions and manure odors. Such environmental benefits have been the major justification for increased public investment in ADS in the United States and many other nations, such as Germany and Demark.

Because more and more farmers are interested in ADS, there is a great need for research and information, especially information that can help farmers to assess the financial feasibility and returns on the basis of their herd size and other characteristics. This study assesses the energy outputs and financial returns of ADS by farm size through a case study in 
Vermont. Specifically, detailed data on the initial investments, production of electricity and other marketable products, operational expenses, and income, collected through surveys of eight operating ADS on dairy farms in Vermont, are used to estimate the return on equity (ROE), return on assets (ROA), net present value (NPV), and internal rate of return (IRR) by farm size. These financial indicators are expected to help farmers who are interested in ADS assess the feasibility and potential financial returns on the basis of their herd size and other factors and to help energy planners and policy makers create and refine policies concerning ADS deployment in Vermont and other regions.

\section{Development of ADS in the United States}

Until the late 1990s, anaerobic digestion technology was widely utilized in the United States for the treatment of municipal waste streams but infrequently adopted on farms or for the treatment of animal manure. Although the number of ADS on American farms has increased significantly in recent years, its development has lagged behind many European nations as well as some developing nations such as China. For example, the United States Environmental Protection Agency's (EPA's) AgSTAR program has estimated that 8,241 commercial livestock farms in the United States are technically and economically feasible sites for ADS but that in 2014 only 247 ADS were operating on these farms, accounting for about $2.9 \%$ of the feasible sites [4]. According to the latest member country reports of the International Energy Agency (IEA) Bioenergy Task 37 (Energy from Biogas), Germany leads the European nations with 7,895 agricultural and biowaste biogas plants, followed by Austria with 291 plants, France with 116 plants, and Switzerland with 115 plants in 2014 [5]. Among the developing nations, China has been a leader, with more than 40 million small biodigesters, most of which were built in the past three decades [6].
A traditional dairy state in the United States, Vermont had its first ADS installed in 1982, but there was no further ADS development for more than 20 years, until the second ADS was installed in 2004 [7]. The number of operating ADS on Vermont farms has increased rapidly in the past 10 years, reaching a total of 16 by December 2014 [8]. The development of ADS in Vermont has been closely associated with the Cow Power program (see Wang et al. for a review of the Cow Power program's development and contributions to the expansion of ADS in Vermont [3]).

Under the Cow Power program, electricity customers can choose to purchase $0 \%, 25 \%, 50 \%$, or $100 \%$ of their electricity generated from ADS at a price premium of $\$ 0.04$ per kilowatt-hour $(\mathrm{kWh})$ above their regular electricity rates. Dairy farmers who operate ADS as part of the Cow Power program receive the premium of $\$ 0.04$ per $\mathrm{kWh}$ over the contracted prices for their electricity supplied to the grids as long as consumer demand for Cow Power electricity equals or exceeds the supply. As shown in Figure 1, the monthly consumer demand for Cow Power electricity was greater than the monthly supply until early 2011, but has been significantly lower than the supply since mid-2011. The steady increase in supply and decrease in consumer demand for Cow Power electricity since 2009 has emerged as a major restricting factor for further expansion of the Cow Power program. The program is essentially a financial "first come, first served" situation for those supplying power to the grid. When supply exceeds demand, the newest farms to come online with ADS do not receive the $\$ 0.04$ premium from local electricity customers but they can instead sell their renewable attributes on the Renewable Energy Credits (RECs) market for a premium, usually less than \$0.04 but greater than $\$ 0.02$ per $\mathrm{kWh}$. Great efforts have been made to encourage more electricity customers to support the program through their participation. For example, education programs and materials have been developed to highlight the benefits of the Cow Power program for farmers, local communities, and the environment.



Figure 1. GMP Cow Power ${ }^{T M}$ monthly electricity supply and demand in Vermont. 
In addition to electricity, ADS produce a significant amount of solid fibers as a by-product of digestion. After the manure goes through the digester, the solid and liquid portions are often mechanically separated with a screw press, and the fibrous by-product is used as animal bedding and as compost for amending soil [9]. Because clean bedding is essential to dairy cow health and milk production, securing a supply of bedding material at a reasonable price is very important to farm operations $[10,11]$. Quality bedding material also has the potential to decrease somatic cell counts in milk and enhance milk quality, thus garnering a higher milk price for farmers [12]. The contributions of the solid materials to farm revenue through the sales of such materials as animal bedding or compost and/or through reduction in the purchase of bedding materials will be analyzed in section 4.2 of this paper.

ADS also provide solutions to the challenges of collecting, transporting, and spreading raw dairy cow manure. Cow manure is much more liquid than chicken, pig, or horse manure, and managing liquid manure poses specific logistical challenges. Spreading raw dairy manure is malodorous, exposes the surrounding area and its inhabitants to the pathogens inherently present in dairy manure, and emits methane, a greenhouse gas with 21 times the warming potential of $\mathrm{CO}_{2}[13,14,15]$. Processing manure in ADS and removing the solids after digestion allows farmers to transport only the liquid fraction to crop fields and significantly decreases the odors, pathogens, GHG emissions, and transport cost of manure spreading.

It seems reasonable to predict that the interest in ADS in the United States will continue to grow, given the benefits of increased farm income, locally sourced renewable electricity and other energy products, and reduction of GHG emissions. On the other hand, the financial feasibility and returns on investment from both public and private sources will be a key factor for the future development of ADS. This study is motivated by the growing needs for information on the financial returns of ADS for farms with different sizes and characteristics.

\section{Data and Analysis Methods}

To examine the financial returns of ADS by farm size, operational data were elicited from eight farms with operational ADS in Vermont. Person-to-person interviews were conducted between June 2012 and January 2013 with nine dairy farmers with operating ADS in Vermont. One farmer did not provide adequate data for our financial analysis and was therefore removed from this study. The farms included in this study varied in herd size from 75 to 2,100 cows, and their electricity output ranged from $20 \mathrm{~kW}$ to $450 \mathrm{~kW}$.

All the financial data the farmers had available and were willing to share pertaining to the construction and operation of the ADS were collected in three categories: (a) initial investments and fund sources (design, construction materials, labor, grants, loans, etc.), (b) electricity production and other outputs, and (c) operational expenses and income. The above data were collected from farmers' accounting records, receipts, notes, and other forms of information. All the farmers had reasonably firm numbers or good estimates for their investments, operational costs, and income. However, the quality of the data is subject to many factors. For example, the length of operation ranged from two months to five years and, for the ADS that have been in operation for less than one year, certain estimation approaches were applied to convert some monthly data into annual data. Great efforts were made to enhance the data quality.

The primary data were analyzed to calculate net earnings, ROA, ROE, NPV, and IRR. These commonly used financial indicators together provide a comprehensive measurement of the financial returns of the ADS and can be used to compare the financial returns of ADS with that of other investment projects. The ROE of ADS also has a direct policy application in Vermont as a result of the Vermont Energy Act of 2009. The act (No. 45 H.446) established a standard offer policy for renewable energy plants in which the public service board "shall set the price to be paid to a plant owner...to include a rate of return on equity (ROE) not less than the highest rate of return on equity (ROE) received by a Vermont investor-owner retail electric provider." Farmers may wish to use the indicators to compare ADS with other potential investments such as producing artisan cheese on the farm, and policymakers may use the indicators to evaluate the implementation and impacts of the energy act.

For depreciation costs, a 7-year schedule was used for equipment such as the separator, generator, and other equipment with moving parts, and a 10-year depreciation schedule was used for buildings, drainage, connection to the grid, and other structures related to the digester such as the concrete pit and the structures used to house the manure during and after the digestion process. This methodology varies from that employed in the study by Wang et al. in which a 7-year depreciation schedule was used for all components and structures, and is a more accurate reflection of observed investment lifespan [3].

The farms included in this study were sorted by herd size into two groups: small and medium farms with 500 or fewer cows, and large farms with more than 500 cows. Whereas previous studies have focused predominantly on ADS with over 500 cows, and often with 700 or more, this study contributes to the literature with information on the financial returns of ADS on small and medium farms as well. Such information is highly needed in Vermont and other states with relatively more small and medium farms. For example, the average dairy farm size in Vermont is 130 cows, and about $50 \%$ of dairy farms in the state have 500 or fewer cows [16]. In this study, data from individual farms are aggregated into two groups, and the financial indicators are calculated for each group of farms.

Economic benefits of ADS include three major components: (1) sales revenue from electricity at $\$ 0.18$ per $\mathrm{kWh}(\$ 0.14$ as the base price plus $\$ 0.04$ from the Cow Power 
program premium), (2) sales revenue from the solid fiber material as animal bedding or compost, and (3) reduction in dairy operational cost due to the use of solid material as cow bedding and of hot water from the generator to wash milking equipment. While some economic benefits such as the revenue from electricity sales were directly from farm records, other benefits such as the reduction in fuel cost as a result of the use of hot water from the generator were based on inputs from farmers, extension specialists, and others who are knowledgeable about the ADS and dairy operations.

\section{Results and Discussion}

This study has expanded previous research by Wang et al. by analyzing financial returns from a larger number of farms and focusing on the impacts of farm size on the financial returns of ADS [3]. The major characteristics of the eight dairy farms with operational ADS are summarized in Table 1. While the herd size ranges from 75 to 2,100 , two farms are considered to be small, with 200 or fewer cows; another two are medium farms, with 201 to 500 cows; and the remaining four are large farms, with more than 500 cows. The significant variations among the eight farms in herd size, digester type, installed capacity for electricity generation, and other characteristics make this an excellent opportunity for addressing research questions about on-farm ADS. For example, although plug-flow designs have been found in general to be the most effective digester design for the cold climate of the northeastern United States [17], the experience of Vermont suggests that other designs also work in the northeastern United States. The initial investments, funding sources, operational expenses, incomes, and calculated financial indictors by farm size are reported in the rest of this section.

Table 1. Characteristics of the ADS in Vermont.

\begin{tabular}{|c|c|c|c|c|c|}
\hline Farm & Cows & $\begin{array}{l}\text { Installed } \\
\text { capacity }^{1} \\
(\mathrm{~kW})\end{array}$ & $\begin{array}{l}\text { Installed } \\
\text { kW per } \\
\text { cow }\end{array}$ & Digester type $^{2}$ & $\begin{array}{l}\text { Operational } \\
\text { period }^{3} \\
\text { (months) }^{\text {monthe }}\end{array}$ \\
\hline A & 1,050 & 450 & 0.43 & Plug Flow & 101 \\
\hline B & 2,100 & 300 & 0.14 & Complete Mix & 59 \\
\hline $\mathrm{C}$ & 1,200 & 450 & 0.38 & Plug Flow & 57 \\
\hline D & 1,450 & 450 & 0.31 & Plug Flow & 33 \\
\hline $\mathrm{E}$ & 500 & 155 & 0.31 & Plug Flow & 50 \\
\hline $\mathrm{F}$ & 375 & 150 & 0.40 & Plug Flow & 33 \\
\hline G & 200 & 40 & 0.20 & Covered Lagoon & 12 \\
\hline $\mathrm{H}$ & 75 & 20 & 0.27 & Mod Plug Flow & 26 \\
\hline
\end{tabular}

1. This can be different from the operational capacity as some ADS installed more capacity than the herd size due to grant eligibility or anticipated growth in herd size.

2. See Wilkie for design specifications [21].

3. Number of months since the digester first became operational, as of September, 2015.

Although the herd size and installed capacity of electricity generation vary significantly across farms, the capacity in terms of installed $\mathrm{kW}$ per cow seems to be closely related to the digester type. The plug-flow ADS in this study are installed with generally higher $\mathrm{kW}$-per-cow values, which correlate to higher energy production per cow, than the complete mix, covered lagoon, and modified plug-flow ADS. In general the generator capacity is sized to match the volume of the digestion chamber and the volume of manure generated on the farm. In practice several farms have been able to adjust this relationship by pre-heating manure to shorten the time for complete digestion, therefore increasing the biogas production for undersized digestion chambers. Also, certain grants have been based on the capacity of electricity generation, which may have provided incentives for some farmers to install larger generators.

\subsection{Initial Investment and Funding Sources}

The initial investment is the total cost incurred by dairy farms to build the ADS and includes all planning, design, construction, grid connection, and commissioning costs. As reported in Table 2, the initial investment costs are substantial for farms of all sizes. The average investment is about $80 \%$ greater for large farms than small and medium farms.

Table 2. Average initial investment and funding sources of ADS by farm size in Vermont.

\begin{tabular}{lll}
\hline & \multicolumn{2}{l}{ Herd size (cows) } \\
\hline & $\mathbf{7 5 - 5 0 0}(\mathbf{n}=\mathbf{4})$ & $\mathbf{5 0 1 - 2 , 1 0 0}(\mathbf{n = 4})$ \\
\hline $\begin{array}{l}\text { Average Initial Investments } \\
\text { Engineering and design }\end{array}$ & $\$ 66,077$ & $\$ 441,033$ \\
$\quad \begin{array}{l}\text { Construction labor } \\
\text { Grid interconnection }\end{array}$ & $\$ 164,592$ & $\$ 68,771$ \\
$\quad$ Other (permits, installation) & $\$ 57,347$ & $\$ 255,159$ \\
Co-generation unit, solids & $\$ 213,652$ & $\$ 308,470$ \\
separator, buildings \& other & $\$ 851,154$ & $\$ 1,370,782$ \\
equipment & & \\
$\quad$ Total initial investment & $\$ 1,352,820$ & $\$ 2,444,213$ \\
Average Funding Sources & & \\
$\quad$ Grants & $\$ 1,040,008$ & $\$ 1,403,540$ \\
Loans & $\$ 238,412$ & $\$ 965,673$ \\
Owner's cash \& labor & $\$ 74,400$ & $\$ 75,000$ \\
Total funding & $\$ 1,352,820$ & $\$ 2,444,213$ \\
\hline
\end{tabular}

Due to variation in bookkeeping methods, some large farms apportioned relatively small amounts to construction labor and incorporated a large portion of overall project labor into the category of co-generation unit, solids separator, buildings, and other equipment. Co-generation units are the generators that combust biogas and convert the resulting mechanical energy to electrical energy and capture the thermal energy byproduct. The solids separator removes the liquid fraction from the solid, allowing farms to use or sell the solid fibers as animal bedding or compost. Buildings are required to house these units and other equipment is needed for day-to-day operations. Grid interconnection is a large and highly variable investment cost associated with connecting the electrical generator to the grid and is dependent on the distance from the digester site to the nearest point in the grid capable of accepting new electrical generation input.

The funding sources used to build ADS were loans, farm owner capital and labor contributions, and grant awards. Grants were received from five different sources: the 
Vermont Agency of Agriculture, Farms and Markets, Green Mountain Power via the Renewable Development Fund Program, the U.S. Department of Agriculture (USDA), the Clean Energy Development Fund (CEDF), and the Troubled Assets Relief Program (TARP) federal stimulus program. As shown in Table 2, the level of grant funding is associated with the farm size, with larger operations awarded more absolute grant dollars and small and medium farms awarded a greater proportion of total project cost in grant dollars (76.8\% and $57.4 \%$ respectively).

\subsection{Incomes and Expenses}

As reported in Table 3, incomes from ADS include electricity sales, sales and on-farm use of fibers for animal bedding or compost, savings from reclaimed hot water, and incremental revenue increases from improved milk quality attributable to better animal bedding. Electricity sales provide the largest revenue stream derived from ADS operations. Seven of the eight farmers interviewed take part in the Cow Power program, receiving the feed-in-tariff (FIT) rate of $\$ 0.141$ per $\mathrm{kWh}$ plus a $\$ 0.04$ per $\mathrm{kWh}$ customer-provided premium. The remaining farm uses a net metering agreement to utilize their electricity for farm use and then collects the electricity income for the remainder that helps power the regional grid.

Table 3. Incomes and expenses of ADS by farm size in Vermont.

\begin{tabular}{|c|c|c|}
\hline & \multicolumn{2}{|c|}{ Herd size (cows) } \\
\hline & $75-500(n=4)$ & $501-2,100(n=4)$ \\
\hline \multicolumn{3}{|l|}{ Income } \\
\hline Electricity sales & $\$ 55,524$ & $\$ 374,651$ \\
\hline Bedding on-farm \& sales & $\$ 16,220$ & $\$ 78,125$ \\
\hline Other income & $\$ 7,093$ & $\$ 28,225$ \\
\hline Total annual income & $\$ 78,837$ & $\$ 481,001$ \\
\hline \multicolumn{3}{|l|}{ Expenses } \\
\hline Maintenance and repairs & $\$ 8,185$ & $\$ 55,866$ \\
\hline Labor & $\$ 7,571$ & $\$ 17,215$ \\
\hline Interest payments & $\$ 7,266$ & $\$ 38,277$ \\
\hline Insurance & $\$ 792$ & $\$ 5,736$ \\
\hline Oil and fuel & $\$ 11,681$ & $\$ 11,939$ \\
\hline Other expenses & $\$ 6,371$ & $\$ 4,705$ \\
\hline Total annual expenses & $\$ 41,866$ & $\$ 133,737$ \\
\hline \multicolumn{3}{|l|}{ Net Earnings } \\
\hline Net annual income & $\$ 36,971$ & $\$ 347,263$ \\
\hline Annual depreciation costs & $\$ 27,988$ & $\$ 67,599$ \\
\hline Net annual earnings $^{1}$ & $\$ 8,983$ & $\$ 279,664$ \\
\hline
\end{tabular}

${ }^{1}$ Net Annual Earnings=Net Annual Income-Annual Depreciation cost.

Fibers to be used for animal bedding or landscaping purposes provide another significant source of revenue and avoided costs. Some farms reported offsetting their entire need for bedding, and some also had fibers left over to sell as a garden supplement or to other farms as bedding. Although several farmers sold bedding, it was done sporadically and on a small scale, so the market price per unit is undetermined. Based on some primary data as well as estimation, the large farms saw an average of $\$ 78,125$ per year in savings and income from bedding, while small and medium sized farms recorded $\$ 16,220$ per year.
Heat of combustion from electrical generators is captured from hot water jackets, engine exhaust, and cooling apparatus. Some farms utilize this heat to offset the need for propane or other fuels to heat structures such as barns, shops, or other buildings. Annual fuel cost savings were estimated to be $\$ 18,000$ for large farms and $\$ 4,400$ for small and medium farms.

As another benefit, some farmers asserted that the improved bedding from the digester directly resulted in improved milk quality. High-quality bedding can potentially lower somatic cell counts in the cows' milk, which will thus earn a higher milk premium. This benefit is averaged and included in 'other income' for large farms. The benefit is calculated based on a $\$ 0.004$ premium per hundredweight (cwt) for 22 million cwt of milk sales at this improved level annually, resulting in a milk income increase of $\$ 88,000$ for the one farm quantifying the benefit. Other farms did not quantify this benefit.

Operational expenses are the recurring expenses associated with ADS operations and include maintenance and repairs, tax increases attributable to ADS installation, routine labor, oil and fuel, office supplies, insurance, and interest on loans. Office expenditures include accounting labor, office supplies, and legal guidance. Insurance includes general liability of the digester, as well as equipment and income loss policies. Maintenance and repairs are all repairs performed on the engine, digester, and buildings either regularly or sporadically since the digester began operating. In some cases, there were no expenses in this category as the farms had not been in operation long enough for equipment to need repair.

One of the two small to medium farms (500 or fewer cows) in this data set had not been operating for long enough to obtain maintenance data, while another had signed a maintenance contract with the digester engineer that would cover all the maintenance costs related to the digester over the next five years for $\$ 4,500$ per year. Although the technologies were different for these systems, it is assumed for the purposes of this study that the maintenance costs would be roughly similar.

Labor for maintenance and repairs accounted for routine, non-specialized labor such as oil changes. "On farm" labor includes labor on the digester by the farmers or other employees of the farm, whereas "off farm" labor includes labor hired specifically for the digester, often for specialized repairs on the engine, or other specialized labor regarding the separator or pumps. Farmers estimated spending 1-2 hours per day checking digester operations, including pumps, flow, electricity production, and so on. The cost of on-farm labor was assumed to be $\$ 20$ per hour, and off-farm hired labor was assumed to be $\$ 65$ per hour.

Taxes include any increase in town taxes as a result of the construction of new buildings and the digester unit. This assessment varies from town to town, as some of the buildings used to house the generator are also used as storage for farm equipment, which results in a different classification and tax assessment. 


\subsection{ROE, ROA, NPV and IRR}

A cost-return analysis for the eight farms including initial investment, net earnings, ROE, ROA, 7-year NPV of investment, and IRR is summarized in Table 4. ROE is calculated as net earnings divided by average equity, while ROA is calculated as net earnings plus annual interest expenses divided by average assets. NPV is an indicator of the value of an investment expressed in a future expected value of money and is calculated using the following equation and a $7.5 \%$ discount rate:

$$
N P V=\sum_{i=1}^{n} \frac{\text { values }_{i}}{\left(1+\text { rate }^{i}\right.}
$$

Table 4. Financial returns of ADS by farm size in Vermont.

\begin{tabular}{lll}
\hline & Herd size (cows) & \\
\hline & $\mathbf{7 5 - 5 0 0}(\mathbf{n}=\mathbf{4})$ & $\mathbf{5 0 1}-\mathbf{2 , 1 0 0}(\mathbf{n}=\mathbf{4})$ \\
\hline Total initial cost & $\$ 1,352,820$ & $\$ 2,444,213$ \\
Initial farm cost (initial & $\$ 312,812$ & $\$ 1,040,673$ \\
investment - grants) & $\$ 8,983$ & $\$ 279,665$ \\
Net annual earnings & $0.73 \%$ & $12.54 \%$ \\
ROE & $1.07 \%$ & $13.50 \%$ \\
ROA & $(\$ 1,351,155)$ & $(\$ 487,973)$ \\
NPV based on total cost & $(\$ 300,912)$ & $\$ 817,646$ \\
NPV based on farm cost & $(39.0 \%)$ & $2.73 \%$ \\
IRR based on total cost & $(17.8 \%)$ & $27.15 \%$ \\
IRR based on farm cost & & \\
\hline
\end{tabular}

IRR is a budgeting tool used to evaluate the projected capital growth rate a project generates. IRR is equal to the discount rate required to make the NPV over the projected lifespan of the investment exactly equal to zero. A higher IRR indicates a more desirable rate of return on the investment.

NPV and IRR are examined based on total system cost and farm cost (initial cost minus grants). As government and public utility funds provide grants for ADS projects, financial performance based on total cost allows us to examine returns based on net societal benefits. Since grant providers are not financially invested in ADS returns after the grants are awarded, financial analysis based on total cost does not reflect actual outcomes of stakeholders, but rather a means of evaluating the total financial performance of the investment. NPV and IRR are also examined based on farm cost. Farm cost analysis indicates the actual economic performance as it is realized by farms. NPV and IRR based on farm cost are calculated using initial costs equal to the amount financed by loans and owner capital and labor input.

One of the largest factors in a farmer's decision to build $\mathrm{ADS}$ is the economic return the system provides. ROE, ROA, $\mathrm{NPV}$, and IRR values indicate the variations in system economic benefits that are a result of dairy herd size and the correlated ADS size. Overall, investment in large digester systems provides the most beneficial financial returns, realizing positive ROE and ROA, IRR and NPV based on farm cost. Medium and small operations, on the other hand, do not see a significantly positive return based on these indicators. This is primarily because as system size increases, the marginal increase in initial investment is significantly smaller than the marginal increase in electricity revenue, given the much larger volumes of manure that can be processed.

Each farm presents a unique case, with varying ADS design and capacity, topography, and geology altering costs and income potential between farms. External factors, such as loan amounts, grant awards, and electricity prices, also varied, influencing cash flow, ROA, ROE, NPV, and IRR. Given the current average grants and energy price available to those farmers operating ADS with more than 500 cows, the financial returns are very attractive, resulting in significantly positive rate-of-return values. A competing investment would need to provide a $27.15 \%$ or better annual rate of return to present a better alternative to ADS investment. This is a very good investment for these large farms.

Small and medium farms are facing challenges in making ADS economically viable. For systems operating with 75500 cows, there are positive net annual earnings; however, under the current cost and pricing situations, these earnings are not sufficient to yield positive NPV and IRR, indicating that competing investment opportunities could provide better alternatives. Small and medium farms are realizing approximately $1 \% \mathrm{ROE}$ and $\mathrm{ROA}$ which is insufficient to pay for the initial costs of the system over the expected life of the investment. It should be noted that these financial returns do not account for non-monetary benefits of ADS such as reduced farm odors and pathogens, improved manure management, reduced GHG emissions, and reduced farm runoff-all benefits that should be considered alongside financial returns.

For small and medium farms, the financial returns are challenging when compared with larger operations. Given the average energy-generation capacity of approximately $122,000 \mathrm{kWh}$ per year, small and medium ADS operations do not produce the volume of electricity needed to keep up with the debt service and maintenance costs of the system. Likewise, the bedding production is insufficient to generate a financial offset large enough to justify the investment on economic benefits alone. It is still unknown what the actual maintenance costs will be over the long term for these systems as many have not been operating long enough to gather extensive maintenance data.

The initial costs are relatively huge for small and medium farms considering ADS adoption, and without the help of grants it would be almost impossible to proceed. One dairy farmer stated, "People laughed at me when I told them we had 200 cows, so we increased the herd to 375 to even be considered." Economy of scale is a particular barrier to small and medium farms because costs do not step down linearly with smaller system size. One way to examine this is to calculate investment cost per cow. Given the total investment required for ADS, presented in Table 3, a large farm with 1,200 head would need to invest on average $\$ 2,147$ per cow. A small farm with 150 head would need to invest on average $\$ 5,079$ per cow, which is more than twice the per-cow 
expense. Small farms also do not fare as well as larger farms on a per-cow income basis. While the 1,200-head farm will on average realize an annual revenue stream of about $\$ 424$ per cow, a 150-head farm can expect revenue closer to $\$ 218$ per cow. The compounding factors of higher expense and lower income per cow for small farms highlights why these operations suffer poor cash-flow returns from ADS.

Dairy farmers have noted the benefit of input cost stability and operational independence as a factor in deciding to install ADS. Cutting operating costs and making bedding supply more secure were major factors in the decision making process, even in the face of unknown economic viability of the systems. Electricity prices have been rising over the past few decades, and some farmers that are using net-metering view the digester as a way to hedge against expected increases in electricity prices. Past experiences with timber by-product bedding indicate that hedging against volatile bedding costs by producing one's own fibers may also be an effective means of hedging against future uncertainty.

\subsection{Additional Findings}

As further justification for ADS implementation, farmers discussed the importance of strategic career diversification to make the business more interesting to themselves and to future generations. One farmer indicated, "I was sick of the dairy farming part and wanted something different. I am 57, and none of my kids wants to get into dairy farming." Diversification of farm enterprises is a means for farmers to expand the types of work available on the farm and provide more interest for aspiring dairy men and women.

Odor reduction was another factor in the decision for farmers to build ADS. Some saw this as purely a side-benefit, and for most it played only a small role in the decision process. Farmers indicated, however, that it allowed for improved neighbor relations, as complaints are often made regarding the odor of the manure on dairy farms.

Many farmers stated that the ultimate deciding factor in building the digester was the financial support from public grants. It is important to note that the federal stimulus program grant (TARP) was the only nontaxable grant, whereas all other grants presented the burden of being considered taxable income for the farmer. The nontaxable TARP grant provided a significant bonus to the farmers who utilized those funds.

The availability of grant funding was especially important because digester technology and profitability were largely unknown to the farmers when they were deciding whether to build ADS on their farms. Farmers knew they were investing in a potentially risky business venture-and for some the venture seemed even riskier given their age and outlook. One farmer who operates a 100-cow dairy revealed that, without the grants, his projected payback period would have been longer than 10 years. Because the grants decreased this projected payback period, however, he decided to build the system. Another farmer related that it took effort to convince the older generations involved in the farm operation to invest in the technology, as the farm was owned across three generations. He explained that investment in ADS would provide him with the opportunity to return to the farm while running a project separate from the milk production. $\mathrm{He}$ indicated that the potential cash flow increase convinced the older generations to invest in the system.

\section{Conclusions and Potential Policy Implications}

For the purpose of assessing the investments, energy outputs, and financial returns of on-farm ADS by herd size, this study has collected primary data from eight dairy farms with operating ADS in Vermont and used the data to calculate the ROE, ROA, NPV, and IRR for small and medium (75-500 cows), and large (501-2,100 cows) dairy farms. This study suggests four major conclusions and potential policy implications.

First, ADS developed in the United States favor large farms in terms of electricity outputs and financial returns, and it is a huge challenge for small and medium farms to invest in and maintain ADS. Large-farm ADS realize an ROE of $12.54 \%$ and an ROA of $13.50 \%$ and have attracted more large farms to adopt the technology. Small and medium farms in this study realized positive net annual earnings, but, based on the depreciation rates, net earnings are insufficient to realize positive NPV and IRR. As it is, given the current energy prices of $\$ 0.16-\$ 0.18$ per $\mathrm{kWh}$ and existing levels of grant support, small and medium farms struggle to generate enough revenue to cover the annual operating expenses of ADS operations, let alone recoup the initial investment.

These economic outcomes are in part attributable to the fact that ADS investment cost and maintenance expenses do not step down linearly as herd size decreases. The per-cow cost to build ADS on a large farm is less than half that on a small or medium farm. At the same time, per-cow revenues are nearly two times as high on large farms as on small and medium farms. These are major barriers that will need to be addressed by technical and policy changes if adoption of ADS is to occur in a manner accessible to all sizes of dairy farms.

Second, current levels of public support from grants and technical assistance from government and utility entities support ADS deployment adequately at large-scale farms but insufficiently at small and medium farms. While the percentage of grants to total investment in this study is greater for small and medium farms $(77 \%)$ than large farms (56\%), small and medium farms still do not achieve economic sustainability. Rather, the disparity between investment and returns is so large for small and medium farms that stand-alone ADS on those farms simply may not make economic sense in certain cases. Public funds may be better used to continue support of stand-alone systems on large farms and to spur technical and operational solutions, such as shared, regional ADS facilities (See Thompson et 
al. for a study on the feasibility of centralized ADS in Addison County, Vermont [18]).

Third, support from energy consumers and the public has been vital to the economic success of ADS. The electricity customer-provided premium of $\$ 0.04$ per $\mathrm{kWh}$ has supported the economic sustainability of ADS in Vermont, but recent growth in Cow Power supply has outstripped customer demand, making it more difficult for farms with ADS to secure the required revenue to support ADS operations. Consumer education about ADS technology, its renewable-energy attributes, and its role in supporting regional agriculture will be necessary to promote markets and grow demand for ADS energy.

In addition to the promotion of markets for on-farmgenerated renewable energy and by-products of ADS, technology sharing between companies, especially those making use of public funds, should be promoted [19]. This would advance some of the original motivations of investing in ADS technology, such as securing renewable and locally sourced energy generation. Technology sharing is a contentious issue, however, given the patent and proprietary information laws in place to protect private entities from intellectual property infringement. Incentives by which companies are encouraged to share information should be explored; for example, public funds may require technology sharing as a condition for accessing the funds. Such openness will be instrumental in the efficient development of further ADS.

Finally, it is clear that economic performance of on-farm ADS varies significantly between farm operations. Herd size, production practices, and manure management logistics all affect the economic performance of ADS. To date, ADS deployment has been primarily focused on one model: independent ADS for each farm based on varying scales of the same industrial-scale, capital-intensive model. This has worked very well for large farms, particularly when grants and energy premiums are available. Even with these supports in place ADS development has not proven to be financially effective for many farms with fewer than 500 cows. Alternative technical, social, and financial models are needed.

For example, it may be possible to implement community-scale ADS serving multiple small and medium farms within the same geographic regions [18]. Indeed, in the European Union nations of Germany, Denmark, France, Austria, and the United Kingdom, community-scale ADS have been implemented to process manure from multiple farms as well as food processing waste and municipal organic residuals. These ADS facilities are industrial scale but rely on very specific siting and sizing criteria to optimize performance within the existing transportation and organic waste network. Alternatively, in China as many as 40 million very small-scale ADS have been implemented on rural homesteads [20], using simple technologies and low capital input models. Both of these alternatives may be explored as potential pathways for ADS deployment in the United States to make ADS economically viable for more sizes and types of farms.
To date, ADS deployment in Vermont has been largely experimental, despite occurring at a per-farm rate as high as in any U.S. state. Interview data indicate there is vast room for improvement, given some of the lessons that have been learned through the arduous process of constructing and running these systems. If these lessons are taken into account, and shared broadly, there is the potential to lower costs by avoiding the pitfalls of early adopters. For example, the handling of manure in Vermont's cold climate, especially during the winter, has required costly pumping and piping systems to be replaced or repaired on several farms, an experience that suggests using different approaches in the next round of ADS construction. Farmers have also found the need to preheat the manure before it goes through the digester because the microbes are not active until a minimum temperature is achieved. Some farmers noted that using propane to heat the manure in this way has been a large and unexpected cost.

Ultimately the motives of Vermont's early adopters in ADS technology can be summed up by this quote from one of the dairy farmers, in regards to investment in the technology: "We are always trying to be progressive without being stupid." This outlook underscores the pragmatism of a community of farmers willing to adapt to 21 st-century challenges while holding firm to the values of common sense and fiscal responsibility. The dairy farmers who provided data for this study have helped increase understanding of the economic factors influencing ADS adoption and the many non-economic incentives, including securing affordable bedding, improving environmental outcomes related to manure management and methane emissions, and improving neighbor relations by reducing farm odors. To realize these benefits, it will be necessary for many small and medium farms to explore alternate ADS deployment models and to find support from markets that create incentives for investment in ADS, such as formal markets for methane and/or carbon offsets, nutrient cycling, and improved manure management practices.

\section{References}

[1] Vermont Agency of Agriculture, Food \& Markets. (2015). Vermont Dairy: The Number of Dairy Farms in Vermont. Retrieved from http://www.vermontdairy.com/learn/numberof-farms/

[2] MacDonald, J. M., O’Donoghue, E. J., McBride, W. D., Nehring, R. F., Sandretto, C. L., \& Mosheim, R. (2007). Profits, Costs, and the Changing Structure of Dairy Farming (No. ERR-47). Economic Research Service / USDA.

[3] Wang, Q., Thompson, E., Parsons, R., Rogers, G., \& Dunn, D. (2011). Economic feasibility of converting cow manure to electricity: A case study of the CVPS Cow Power program in Vermont. Journal of Dairy Science, 94 (10), 4937-4949. doi:10.3168/jds.2010-4124.

[4] U. S. Environmental Protection Agency. (2015). AgSTAR Digesters. Retrieved from http://www.epa.gov/agstar/agstardata-and-trends. 
[5] IEA Bioenergy. (2014). Economic Sustainability of Manure Based Centralised Co-Digestion. Retrieved from http://www.ieabiogas.net/files/daten-redaktion/download/publications/countryreports/november2013/Countryreport2013.pdf

[6] Wang, Q., Thompson, E. (pending). Converting animal manure into energy products through on-farm biodigesters: A comparative analysis of the development in the U.S. and China.

[7] Raker, M. (2011). CVPS Renewable Development Fund: Progress Report. CVPS Renewable Development Fund Executive Committee.

[8] U. S. Environmental Protection Agency. (2014). AgStar: Operating Anaerobic Digester Projects. Retrieved February 24, 2014, from http://www.epa.gov/agstar/projects/

[9] Kearney, T. E., Larkin, M. J., \& Levett, P. N. (1993). The effect of slurry storage and anaerobic digestion on survival of pathogenic bacteria. Journal of Applied Microbiology, 74 (1), 86-93.

[10] Hogan, J. S., Smith, K. L., Hoblet, K. H., Todhunter, D. A., Schoenberger, P. S., Hueston, W. D., ... Brockett, B. L. (1989). Bacterial counts in bedding materials used on nine commercial dairies. Journal of Dairy Science, 72 (1), 250-258.

[11] Rendos, J. J., Eberhart, R. J., \& Kesler, E. M. (1975). Microbial populations of teat ends of dairy cows, and bedding materials. Journal of Dairy Science, 58 (10), 1492-1500.

[12] Noordhuizen, J., \& Metz, J. H. M. (2005). Quality control on dairy farms with emphasis on public health, food safety, animal health and welfare. Livestock Production Science, 94 (1), 51-59.

[13] Nicholson, F. A., Groves, S. J., \& Chambers, B. J. (2005). Pathogen survival during livestock manure storage and following land application. Bioresource Technology, 96 (2), 135-143. doi: 10.1016/j.biortech.2004.02.030.

[14] Raizman, E. A., \& Wells, S. 1. (2003). The Distribution of
Mycobacterium avium paratuberculosis in the Environment and its Association with Infected Herds of Minnesota Dairy Farms. Retrieved from http://conservancy.umn.edu/handle/11299/108991

[15] Sischo, W. M., Atwill, E. R., Lanyon, L. E., \& George, J. (2000). Cryptosporidia on dairy farms and the role these farms may have in contaminating surface water supplies in the northeastern United States. Preventive Veterinary Medicine, 43 (4), 253-267. doi: 10.1016/S0167-5877 (99)00107-5.

[16] Gould, B. (2012). USDA Dairy - Number of Operations by Herd Size. Retrieved from http://future.aae.wisc.edu/usda_dairy/dairy_data/index/2

[17] Penn State Extension. (2013). Farm-Based Anaerobic Digestion Practices in the United States - Biogas and Anaerobic Digestion. Retrieved from $\mathrm{http}$ //extension.psu.edu/energy/waste-toenergy/biogas/links/history-of-anaerobic-digestion/farmbased-anaerobic-digestion-practices-in-the-united-states

[18] Thompson, E., Wang, Q., Li, M. (2013). Anaerobic digester systems (ADS) for multiple dairy farms: A GIS analysis for optimal site selection. Energy Policy, 61, 114-124. doi: 10.1016/j.enpol.2013.06.035.

[19] Jansson, A., Hammer, M., Folke, C., \& Costanza, R. (1994). Investing in Natural Capital: The Ecological Economics Approach To Sustainability. Island Press.

[20] Bond, T., \& Templeton, M. R. (2011). History and future of domestic biogas plants in the developing world. Energy for Sustainable Development, 15, 347-354. doi: 10.1016/j.esd.2011.09.003.

[21] Wilkie, A. C. (2005). Anaerobic digestion of dairy manure: Design and process considerations. Dairy Manure Management: Treatment, Handling, and Community Relations, 301-312. 